\title{
Hubungan Sebaya dan Permainan Tradisional pada Keterampilan Sosial dan Emosional Anak Usia Dini
}

\author{
Pahlita Ratri Ramadhani ${ }^{{ }_{1}}$, Puji Yanti Fauziah ${ }^{2} \bowtie$ \\ Pendidikan Anak Usia Dini, Universitas Negeri Yogyakarta ${ }^{1}$ \\ Pendidikan Luar Sekolah, Universitas Negeri Yogyakarta² \\ DOI: $10.31004 /$ obsesi.v4i2.502
}

\begin{abstract}
Abstrak
Tujuan dari penelitian ini adalah untuk menggambarkan hubungan teman sebaya dan permainan tradisional dengan kemampuan sosial dan emosional anak usia dini. Sampel penelitian dari 30 anak yang terdiri dari 10 laki-laki dan 20 perempuan. Sampel penelitian adalah anak-anak berusia 5-6 tahun di wilayah pesisir selatan Kulon Progo. Pengumpulan data dikumpulkan dengan wawancara, observasi, dan dokumentasi. Analisis validitas data dilakukan dengan triangulasi sumber dan teknik. Hasil penelitian menunjukkan bahwa keterampilan sosial dan emosional anak usia dini di pantai selatan Kulon Progo menunjukkan tingkat pencapaian perkembangan yang cukup baik. Hubungan teman sebaya yang positif akan meningkatkan prestasi perkembangan sosial dan emosional anak-anak. Peran orang tua dan guru penting dalam perkembangan sosial anak-anak dan perlu direalisasikan dan dipelajari secara mendalam.
\end{abstract}

Kata Kunci: sosial-emosional; teman; permainan tradisional.

\begin{abstract}
The aim of the research was to described the relationship of peers and traditional games to the social and emotional abilities of early childhood. The research sample of 30 children consisting of 10 boys and 20 girls. The study sample was children aged 5-6 years in the southern coastal area of Kulon Progo. Data collection was collected by interview, observation, and documentation. Data validity analysis was performed by triangulation of sources and techniques. The results showed that the social and emotional skills of young children on the southern coast of Kulon Progo showed a fairly good level of developmental achievement. Positive peer relationships will enhance children's social and emotional developmental performance. The role of parents and teachers is important in children's social development and needs to be realized and studied in depth.
\end{abstract}

Keywords: social-emotional competence; peer relationship; traditional play.

Copyright (c) 2020 Pahlita Ratri Ramadhani, Puji Yanti Fauziah

$\triangle$ Corresponding author :

Email Address : pahlita0404pasca.2018@student.uny.ac.id (Yogyakarta, Indonesia)

Received 14 March 2020, Accepted 22 March 2020, Published 23 March 2020 


\section{PENDAHULUAN}

Periode perkembangan manusia yang paling penting adalah sejak lahir hingga delapan tahun. Selama tahun-tahun ini, seseorang mengalami pencapaian perkembangan dalam hal perkembangan kognitif, perkembangan emosional, kompetensi sosial, dan perkembangan fisik. Anak usia dini memiliki kecepatan membentuk koneksi saraf yang mencapai 1 juta per detik. Koneksi ini dipicu oleh lingkungan yang kaya, penuh kasih, dan terlindungi, dalam konteks pengasuhan yang responsif dan menyenangkan yang memupuk ikatan dan ikatan yang aman, berkontribusi pada perkembangan sosial dan emosional yang positif (Unicef, 2018).

Perkembangan sosial dan emosional dianggap sebagai faktor penting dalam perkembangan anak, terutama mengingat pentingnya kesiapan sekolah anak. Perkembangan sosial dan emosional terdiri dari hubungan yang dimiliki seseorang dengan orang lain, tingkat pengendalian diri, dan motivasi serta ketekunan yang dimiliki seseorang selama suatu kegiatan. Perkembangan sosial dan emosional pada anak terkait dengan bagaimana perasaan anak-anak tentang diri mereka sendiri (seperti kepercayaan diri, selalu takut, bersemangat untuk belajar, bangga dengan budaya mereka, takut akan kesalahan), bagaimana mereka berperilaku (seperti terus-menerus berkelahi, mudah marah, mampu menangani konflik), dan bagaimana mereka berhubungan dengan orang lain, terutama orang-orang yang berarti bagi mereka (misalnya, orang tua, guru, dan teman) (Shala, 2013).

Kompetensi sosial anak adalah kemampuan untuk menjalin dan mempertahankan kontak sosial dalam proses interaksi atas dasar sikap positif diri. Kompetensi komunikatif, atau kompetensi dalam interaksi, adalah sistem pengetahuan psikologis tentang diri sendiri dan orang lain, keterampilan komunikasi, strategi perilaku untuk situasi sosial, yang memungkinkan membangun komunikasi yang efektif sesuai dengan tujuan dan sasaran interaksi interpersonal (Parhomenko, 2014). Pengembangan kompetensi sosial dan emosional merupakan landasan penting bagi anak-anak untuk mencapai kesuksesan di sekolah dan di kehidupan selanjutnya. Sejumlah peneliti telah menunjukkan bahwa anakanak yang memasuki taman kanak-kanak dengan profil kompetensi sosial dan emosional yang lebih positif tidak hanya lebih berhasil dalam mengembangkan sikap positif tentang sekolah dan penyesuaian awal yang berhasil ke sekolah, tetapi juga meningkatkan nilai dan prestasi. Sedangkan seorang anak dengan kompetensi sosial dan emosional yang buruk beresiko memiliki hubungan yang buruk dengan teman sebaya, masalah perilaku, kurangnya prestasi akademik atau mengembangkan masalah kesehatan fisik dan mental (Im et al., 2019).

Membangun persahabatan adalah tujuan penting dari perkembangan sosial anak usia dini. Persahabatan yang dibangun selama tahun-tahun prasekolah menciptakan konteks yang berharga untuk belajar dan melatih keterampilan yang penting bagi perkembangan sosial, kognitif, komunikatif, dan emosional anak-anak. Persahabatan juga bermanfaat bagi anak-anak dengan menciptakan rasa memiliki dan rasa aman yang bahkan dapat mengurangi stres pada anak-anak. Selain itu, anak-anak yang berhasil berteman di masa kecil berkontribusi pada kualitas hidup anak-anak dan penting untuk penyesuaian hidup (Yu et al., 2011).

Persahabatan adalah hubungan yang ada antara satu orang dan orang lain karena ada perasaan saling mencintai di mana mereka akan menghabiskan waktu bermain bersama. Persahabatan pada anak-anak prasekolah terjadi karena minat, kasih sayang, dan timbal balik timbal balik (Carter \& Nutbrown, 2016). Persahabatan adalah hubungan antara seseorang dan orang lain yang memiliki karakteristik kesetaraan, kebersamaan, keintiman, dan timbal balik. Timbal balik adalah keterampilan sosial yang melibatkan pemahaman tentang memberi dan menerima (aspek kognitif) tetapi juga melibatkan aspek emosional (Papadopoulou, 2016). 
Ada beberapa perbedaan antara disiplin pendidikan dan psikologis dalam perhatian yang diberikan pada hubungan perilaku sosial positif dan kesiapan dan keberhasilan sekolah (Buhs \& Ladd, 2001). Anak-anak dengan keterampilan sosial yang lebih buruk lebih mungkin mengalami kesulitan dengan hubungan teman sebaya, dan dengan demikian, secara tidak langsung, dengan penyesuaian sekolah (Keane \& Calkins, 2004). Selain itu, anak-anak dengan keterampilan sosial yang buruk dan hubungan teman sebaya berisiko lebih tinggi untuk akhirnya putus sekolah. Perilaku sosial anak-anak TK memprediksi kontrol diri di kelas pertama (kontrol kemampuan optimal, evaluasi, dan kegiatan mengatur diri sendiri dan perhatian yang memecahkan masalah), yang kemudian memprediksi pencapaian kelas 1 di sekolah dasar (Denham, 2006).

Tahun prasekolah adalah dasar untuk membangun prestasi perkembangan anakanak yang sukses dengan stimulasi yang tepat. Bermain di tahun-tahun prasekolah memungkinkan anak-anak untuk menjelajahi dan memahami dunia di lingkungan sekitarnya, serta menggunakan dan mengembangkan imajinasi dan kreativitas anak-anak. Pendidikan anak usia dini berbeda dari pendidikan di tingkat atas, di mana kegiatan belajar dilakukan dengan belajar sambil bermain (Whitebread, D., Neale, D., Jensen, H., Liu, C. \& S.L., Hopkins, E., Hirsh-Pasek, K. Zosh, 2017). Beberapa penelitian telah menunjukkan bahwa hubungan teman sebaya yang terjadi pada anak usia dini dan permainan tradisional yang dimainkan bersama memiliki pengaruh pada kemampuan sosial dan emosional anakanak (Blazevic, 2016).

Permainan anak-anak tradisional dibentuk oleh budaya lokal dan lingkungan setempat sehingga menciptakan perbedaan di setiap daerah. Permainan anak-anak tradisional sering menggabungkan pengetahuan budaya, nilai-nilai dan keterampilan yang telah muncul dari waktu ke waktu dari hubungan timbal balik antara komunitas tertentu dan lingkungan mereka. permainan anak-anak, proses permainan, dan metode penularan secara efektif terintegrasi dan bentuk pendidikan dan penjangkauan holistik. Bentuk dan isi permainan dapat dianggap sebagai kurikulum yang diimprovisasi secara lokal, suatu proses permainan yang menanamkan semangat olahragawan dan menanamkan nilai-nilai karakter yang penting seperti belajar bermain sebagai sebuah tim, menerima kekalahan, kerendahan hati, dan persaingan sehat di bawah bimbingan orang tua dalam komunitas (Unesco, 2013).

Permainan anak-anak tradisional adalah area penting dalam budaya pedagogis dan tradisi masing-masing kelompok etnis. Permainan tradisional adalah salah satu faktor dasar pengasuhan tradisional. Permainan tradisional adalah konten paling penting yang mengisi ruang subkultur anak-anak. Permainan anak-anak dalam budaya tradisional adalah bidang penting pendidikan dan sosialisasi yang diwujudkan melalui pengembangan otonomi, kreativitas, kebebasan, tanggung jawab, spontanitas, dan aktivitas (Tufekčić, 2016).

Namun, hingga saat ini kenyataan di lapangan masih menemukan masalah dalam hubungan teman sebaya, seperti sulitnya anak beradaptasi dengan lingkungan baru, anak kurang mampu berinteraksi dengan teman, anak lebih suka menyendiri, dan anak merasa tidak aman. Selain itu, kesadaran menggunakan permainan tradisional sebagai alat bermain untuk merangsang aspek perkembangan anak usia dini mulai menghilang. Seiring waktu dan kemajuan teknologi menyebabkan pendidik mengambil keuntungan dari kemajuan teknologi dalam kegiatan pembelajaran anak usia dini.

\section{Hubungan teman sebaya dan kemampuan sosial dan emosional anak-anak}

Keterampilan sosial mulai muncul, mulai dari kontak mata timbal balik antara bayi dan orang dewasa, hingga permainan mengintip, dan peningkatan kapasitas untuk berbagi waktu dan bermain dengan orang lain. Anak-anak bergerak dari bermain dengan orang lain, melalui permainan kooperatif dan munculnya persahabatan yang dipilih dengan teman sebaya. Ini adalah kontinum yang mungkin surut dan mengalir melalui tahun-tahun awal masa kanak-kanak, dan bervariasi dari satu anak ke anak lainnya. Ada keterampilan sosial 
yang semakin canggih yang diperlukan untuk mengembangkan dan memelihara hubungan teman sebaya (McLaughlin et al., 2017).

Hubungan pertemanan akan berkembang sesuai dengan usia anak (Hurlock, 1997), anak akan mengalami kesulitan bersosialisasi dengan teman sebaya jika tidak diarahkan oleh orang dewasa di lingkungan anak. Hubungan teman sebaya memainkan peran penting dalam perkembangan sosial dan emosional anak-anak, di mana anak-anak akan belajar tentang interaksi sosial, kontrol emosional, dan perilaku yang dapat diterima oleh teman (Hay, 2005). Melalui pengetahuan anak-anak tentang nilai persahabatan dapat membantu anak-anak dalam perkembangan sosial dan emosional secara lebih efektif (Gainsley, 2013).

Hubungan teman sebaya penting bagi anak-anak karena teman dapat mengurangi perasaan cemas, kebingungan, dan memberikan kebahagiaan bagi anak-anak. Memiliki teman untuk anak-anak dapat memberikan peluang sosial untuk memahami orang lain (Theobald et al., n.d.). Persahabatan didefinisikan sebagai hubungan antara orang yang terjadi karena kesetaraan, kesetaraan, dan timbal balik. Teman tidak boleh memiliki kekuatan atau otoritas yang sangat berbeda satu sama lain karena mereka memiliki posisi yang sama. Persahabatan cenderung berkembang di antara orang-orang yang memiliki latar belakang sosial, minat, dan kehidupan yang sama baik secara emosional, minat, dan material (Policarpo, 2015).

Hubungan sebaya memiliki peran yang sangat penting dalam sosialisasi, jika hubungan dengan teman sebaya terjalin dengan baik maka akan menghasilkan perilaku yang baik dan dapat diterima di masa depan. Namun, sebaliknya jika hubungannya dengan teman sebaya tidak baik akan mengakibatkan perilaku sosial yang tidak dapat diterima di masa depan. Melalui permainan yang dimainkan bersama anak-anak akan belajar untuk berbagi, mengendalikan dan menyelesaikan konflik, dan mempertahankan dan memelihara hubungan (Blazevic, 2016). Berdasarkan pendapat ini, peneliti menyelidiki hubungan teman sebaya dan pengaruhnya terhadap kemampuan sosial dan emosional anak usia dini.

\section{Permainan tradisional dan kemampuan sosial dan emosional anak-anak}

Bermain adalah kegiatan yang menyenangkan yang dapat dilakukan oleh semua orang mulai dari bayi hingga orang dewasa, misalnya permainan Peekaboo, sepak bola, petak umpet, dan lainnya. Bermain memberikan peluang bagi anak-anak tentang cara menjalin hubungan dengan teman sehingga anak-anak dapat menjadi bagian dari sekelompok teman. Anak-anak yang dapat bermain secara bebas dengan teman sebaya mereka mengembangkan keterampilan untuk melihat sesuatu melalui perspektif orang lain, untuk bekerja sama, membantu, berbagi, dan menyelesaikan masalah (Gleave \& Colehamilton, 2012).

Bermain memiliki beberapa peran termasuk: (a) Bermain itu bermakna. Anak-anak bermain untuk memahami dunia di sekitar mereka, dan menemukan makna dalam pengalaman dengan terhubung dengan sesuatu yang sudah diketahui. Melalui permainan, anak-anak mengekspresikan dan memperluas pemahaman mereka tentang pengalaman mereka; (B) Bermain itu menyenangkan. Bermain memberi kesenangan bagi mereka yang melakukannya. Melalui bermain seseorang akan tersenyum dan tertawa baik secara individu maupun dalam kelompok; (c) Bermain melibatkan anak secara aktif. Anak-anak yang bermain alias akan terlibat aktif dalam permainan yang sedang dimainkan. Melalui kegiatan ini perkembangan fisik, mental dan verbal anak dapat dirangsang; (D) Putar berulang. Anak-anak bermain untuk melatih keterampilan, mencoba berbagai kemungkinan, merevisi hipotesis, dan menemukan tantangan baru yang mengarah pada pembelajaran yang lebih dalam. Karena itu, bermain sering dilakukan berulang kali; (e) Bermain adalah interaksi sosial. Bermain memungkinkan anak-anak untuk mengkomunikasikan ide-ide, untuk memahami orang lain melalui interaksi sosial, membuka jalan untuk membangun pemahaman yang lebih dalam dan hubungan yang lebih kuat (Whitebread, D., Neale, D., Jensen, H., Liu, C. \& S.L., Hopkins, E., Hirsh-Pasek, K. Zosh, 2017). 
Bermain dapat merangsang perkembangan emosional anak-anak untuk belajar menerima, mengekspresikan, dan menyelesaikan masalah dengan cara yang positif. Bermain adalah cara yang paling penting untuk mengembangkan keterampilan sosial dan memperluas empati untuk orang lain dan mengurangi egosentrisme (Lestari \& Prima, 2017). Permainan tradisional adalah alat yang sangat penting untuk merangsang perkembangan emosi, kognitif, dan fisik anak motor pada usia dini (Petrovska et al., 2013). Permainan tradisional memiliki banyak manfaat dalam semua aspek perkembangan anak usia dini yang mencakup perkembangan fisik-motorik, sosial dan emosional, moral, kognitif, dan bahasa (Sulistyaningtyas \& Fauziah, 2019).

Permainan tradisional Jawa untuk anak kecil dikelompokkan menjadi dua, yaitu permainan yang melibatkan gerakan tubuh atau fisik (Sobyung, Amar -ambahLemah, Obarabir, Jethungan atau Dhelikan, Bedhekan atau TutupTutup, Dhakon, Sundamanda atau Engklek, Tumbaran, dan Simbar Suru) sebagai juga permainan yang melibatkan gerakan dan lagu (Cublak-cublak Suweng, Jamuran, Gundhul-gundhul Pacul, Jaranan, Uler Keket, Kidang Talun, Kursi Jebol, Lagu Kacang Goreng, Sluku-sluku Bathok, Siji Loro Telu, Menthog-menthog, Buta-sangat berbeda) Pitik Walik Jambul, Kupu Kuwi, Iwak Emas, Jo PraKanca, Cah Dolan, I DuwePitik, Bang Wis Rahina, Kembang Mai, dan Saburan (Nur Aisyah, 2017). Dalam studi ini, para peneliti mengeksplorasi berbagai permainan tradisional di Jawa dan pengaruhnya terhadap kemampuan sosial dan emosional anak usia dini.

Berdasarkan hasil pengamatan yang dilakukan di wilayah pesisir selatan Kulon Progo menunjukkan bahwa anak usia dini memiliki kompetensi sosial emosional yang baik. Daerah pesisir sering dikenal sebagai salah satu daerah yang kurang berkembang, orangorang dengan status sosial dan ekonomi rendah, sebagian besar orang yang bekerja sebagai nelayan dan petani, memiliki kesadaran pendidikan yang rendah. Namun, ada yang berbeda dari kondisi orang-orang di wilayah pantai selatan di mana orang sudah memiliki kesadaran pendidikan awal, kesejahteraan sosial dan ekonomi yang baik, dan mampu mengikuti perkembangan zaman.

Anak usia dini di wilayah pesisir selatan Kulon Progo dapat berinteraksi dengan bermain dengan teman-teman seusia, anak-anak juga merasa percaya diri, mau berbagi, mampu membuang sampah yang sudah dibuang ke tempat sampah, dan ingin meminta maaf jika mereka melakukan kesalahan. Anak-anak menggunakan waktu luang mereka dengan bermain bersama teman-teman menggunakan permainan tradisional seperti Dhelikan, Engklek, Jamuran, Cublak-cublak Suweng, Dhingklik oglak-aglik, Dhakon, Gobak Sodor.

Penelitian ini bertujuan untuk mendeskripsikan hubungan teman sebaya dan permainan tradisional dengan kompetensi sosial dan emosional anak usia dini di wilayah pesisir selatan Kulon Progo. Keberadaan penelitian ini diharapkan dapat memperluas perspektif pembaca dan mengubah perspektif masyarakat bahwa tidak semua wilayah pesisir memiliki sumber daya manusia yang berkualitas lebih rendah.

\section{METODOLOGI}

Jenis penelitian yang digunakan dalam penelitian ini adalah pendekatan deskriptif kualitatif. Penelitian ini bertujuan untuk menggambarkan secara terperinci dan mendalam hubungan teman sebaya dan permainan tradisional dengan keterampilan sosial dan emosional anak usia dini di wilayah pesisir pantai selatan Kulon Progo. Kelompok studi terdiri dari 30 anak berusia 5-6 tahun di wilayah pesisir selatan Kulon Progo. Dari peserta, 33,33\% (10 anak) adalah laki-laki sedangkan 66,67\% (20 anak) adalah perempuan. Teknik pengumpulan data yang digunakan dalam penelitian ini adalah observasi, wawancara, dan dokumentasi. 
Berikut ini merupakan tahap pelaksanaan penelitian:

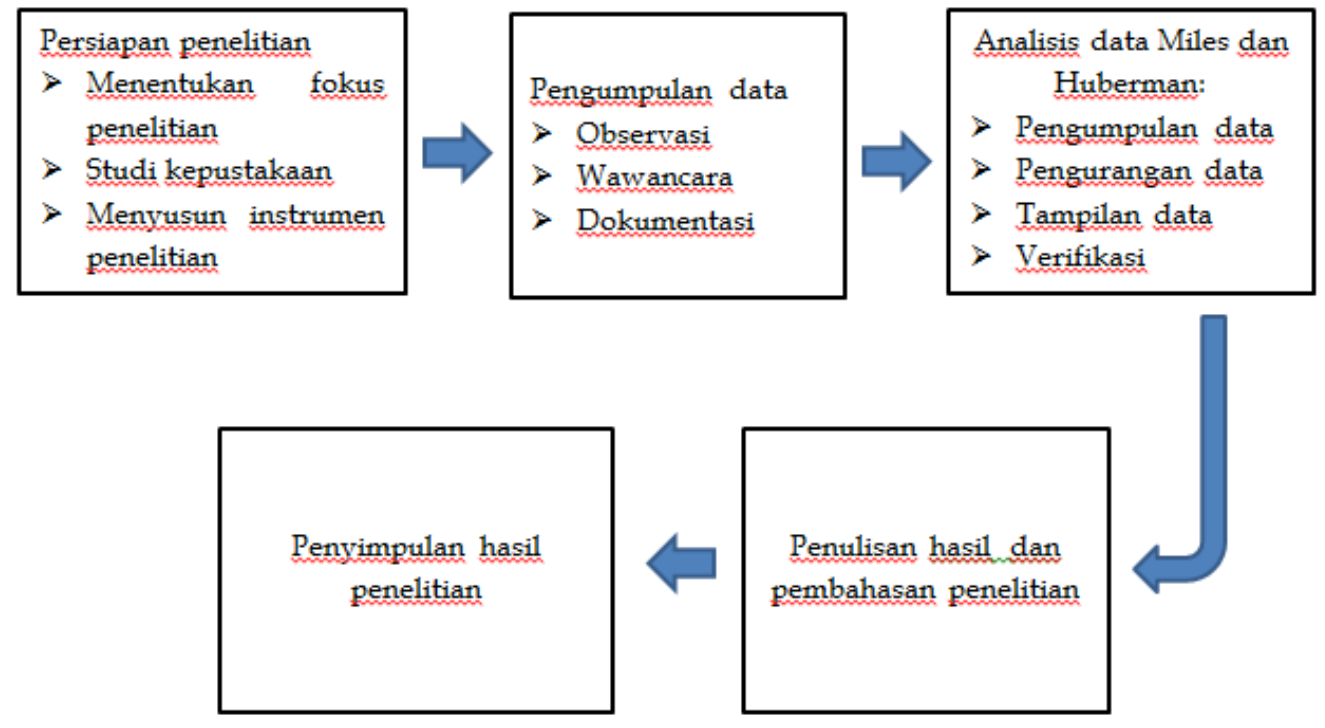

Gambar 1 Tahap Pelaksanaan Penelitian

\section{HASIL DAN PEMBAHASAN}

Wilayah pesisir adalah daerah yang terletak di sekitar pantai. Secara umum, masyarakat pesisir menganggap bahwa penduduk di pantai memiliki status sosial dan ekonomi yang rendah, kurangnya kesadaran akan pendidikan, dan kurang mampu mengikuti perkembangan zaman. Masyarakat pesisir dikenal karena mata pencaharian mereka sebagai nelayan atau petani dengan pendapatan rata-rata yang hanya cukup untuk kebutuhan sehari-hari mereka. Bahkan ketika mereka tidak mendapatkan tangkapan ikan atau musim panen belum tiba, mereka sering merasa kurang. Ini berdampak pada rendahnya tingkat pendidikan masyarakat. Kesejahteraan sosial dan ekonomi masyarakat juga berdampak pada ketidakmampuan masyarakat untuk mengikuti perkembangan zaman, seperti kemajuan teknologi.

Berbeda dengan pandangan masyarakat umum di atas, kehidupan masyarakat pantai selatan di Kulon Progo dapat dikatakan memiliki tingkat kesejahteraan sosial dan ekonomi menengah ke atas. Masyarakat menyadari bahwa kehidupan yang mereka jalani harus dapat berkembang menjadi lebih baik. Oleh karena itu, masyarakat bekerja sama untuk menciptakan bisnis "tambak udang". Hasil yang diperoleh dari petambak udang dapat meningkatkan pendapatan masyarakat sehingga jauh dari kata-kata. Selain itu, orang juga dapat mengikuti perkembangan zaman dengan adanya "tambak udang" yang dikirim ke berbagai daerah dengan promosi melalui media sosial.

Selain itu, masyarakat juga mulai menyadari pentingnya pendidikan untuk anakanak, terutama pendidikan sejak usia dini. Masyarakat bekerja sama dengan lembaga pendidikan anak usia dini untuk mendirikan taman kanak-kanak dengan fasilitas lengkap. Dibandingkan dengan taman kanak-kanak lain yang sama-sama di daerah pedesaan, taman kanak-kanak di daerah pantai selatan di Kulon Progo agak lebih baik. Bangunan luas, berbagai peralatan taman bermain outdoor dan indoor, pendidik yang kompeten, dan sekolah terakreditasi adalah A. Orang tua bersedia memberikan bantuan ke taman kanakkanak jika ada sesuatu yang dibutuhkan untuk kebutuhan proses pendidikan.

Anak usia dini adalah anak sejak lahir hingga usia delapan tahun. Pada usia itu anakanak berada di tahun-tahun emas mereka sehingga mereka mengalami pertumbuhan dan perkembangan yang cepat (Unicef, 2018). Karena kesadaran orang tua di pantai selatan Kulon Progo tentang pentingnya pendidikan untuk anak usia dini, sejak anak-anak berusia empat tahun telah dimasukkan dalam lembaga pendidikan anak usia dini setempat. Orang 
tua berharap bahwa keberadaan lembaga seperti itu dapat membantu anak-anak untuk mengoptimalkan aspek perkembangan. Para orang tua percaya bahwa dengan bantuan pendidik yang kompeten di bidangnya dan fasilitas pendukung dapat memberikan stimulasi yang tepat untuk perkembangan anak.

Perkembangan sosial dan emosional merupakan faktor penting dalam perkembangan anak. Perkembangan sosial dan emosional terdiri dari hubungan antara individu dengan individu lain dan individu dengan kelompok, cara mengendalikan perasaan, dan bagaimana berperilaku agar diterima sebagai anggota masyarakat (Shala, 2013). Seorang anak perlu dibekali dengan pengetahuan tentang bagaimana bersosialisasi dengan orang lain di sekitarnya. Pengamatan menunjukkan bahwa anak-anak di pantai selatan Kulon Progo menunjukkan perilaku positif dalam perkembangan sosial dan emosional.

Hasil penelitian menunjukkan bahwa hubungan teman sebaya pada usia dini berdampak pada kemampuan sosial dan emosional anak-anak. Peneliti menemukan bahwa anak-anak di pantai selatan di Kulon Progo suka bermain dengan teman-teman dengan permainan tradisional karena mereka dapat dimainkan kapan saja dan instrumen yang diperlukan mudah tersedia. Permainan tradisional yang dimainkan oleh anak-anak memberikan pengalaman positif bagi anak-anak sehingga anak-anak belajar mengendalikan emosi mereka. Memberikan kesempatan bagi anak-anak untuk bermain dengan temanteman mereka dapat meningkatkan keterampilan sosial dan emosional anak-anak. Orang tua dan guru memainkan peran penting dalam mengarahkan anak-anak untuk bersosialisasi dengan orang lain. Sedangkan sikap orang tua yang terlalu mengatur hubungan teman anak dapat menghambat peningkatan prestasi perkembangan sosial dan emosional anak.

Peneliti menemukan bahwa anak-anak dapat berinteraksi dengan teman sebaya, walaupun ada tiga anak yang lebih sering sendirian. Salah satu dari tiga anak itu adalah pendatang baru dari luar kota, sedangkan dua anak lainnya lebih suka bermain sendiri berdasarkan penjelasan guru. Mengetahui hal ini guru selalu memberikan stimulasi kepada anak-anak. Misalnya, ketika kegiatan bermain anak-anak yang cenderung sendirian dikelompokkan dengan anak-anak yang aktif dalam kegiatan, memberikan kesempatan bagi anak-anak untuk mengekspresikan pendapat mereka, dan mengajar anak-anak untuk berbagi dengan teman-teman mereka. Orang dewasa di sekitar anak-anak memainkan peran penting dalam mengarahkan anak-anak untuk dapat bersosialisasi dengan teman sebaya (Hurlock, 1997). Tanpa arahan dari orang tua, kemungkinan anak akan mengalami kesulitan bersosialisasi baik dengan teman sebaya maupun dengan orang lain.

Hubungan teman sebaya pada usia dini memainkan peran penting dalam perkembangan sosial dan emosional anak-anak. Melalui hubungan inilah anak-anak belajar tentang cara berinteraksi dengan teman. Anak-anak belajar berperilaku sesuai dengan teman-teman lain untuk menjadi anggota kelompok teman-teman. Anak-anak belajar tentang kebutuhan, pikiran, dan emosi orang lain yang dapat membantu anak-anak membangun persahabatan. Pada saat yang sama, memiliki teman dan menghabiskan waktu bersama memungkinkan anak-anak untuk mengembangkan keterampilan kognitif, sosial dan emosional, meningkatkan harga diri, memiliki rasa berbagi, dan memuaskan kebutuhan anak untuk teman-teman (Papadopoulou, 2016).

Anak-anak di pantai selatan Kulon Progo senang bermain dengan teman-teman mereka. Melalui permainan, anak-anak menemukan pengetahuan mereka tentang berbagai hal. Sejalan dengan ini, Piaget menyatakan bahwa anak-anak belajar tentang terbentuk melalui pengalaman langsung. Oleh karena itu, guru dalam pendidikan anak usia dini menggunakan game untuk mendidik siswa mereka (Clements , D., \& Sarama, 2009). Guru memperkenalkan anak-anak ke permainan tradisional di DIY. Permainan tradisional menggunakan alat dan bahan yang mudah ditemukan di sekitar anak-anak sehingga anakanak dapat memainkannya kapan saja dan di mana saja. 
Dhelikan, Gobak Sodor, dan Engklek adalah game yang sering dimainkan oleh anakanak karena mereka tidak menggunakan alat permainan. Permainan Dhelikan biasanya dimainkan oleh 5-8 anak yang terdiri dari perempuan dan laki-laki. Sedangkan game Gobak Sodor lebih disukai oleh anak laki-laki. Permainan Engklek dilakukan oleh setidaknya 6 anak. Engklek adalah game yang digandrungi anak perempuan. Melalui permainan tradisional dengan teman-teman, Anda dapat mengalami hubungan sosial yang positif. Hubungan anak dengan teman-temannya yang lebih kompeten secara sosial menunjukkan keterampilan yang lebih baik dalam beradaptasi dengan perubahan dan mampu bekerja dengan teman-temannya dalam kegiatan belajar (van Hoogdalem et al., 2013).
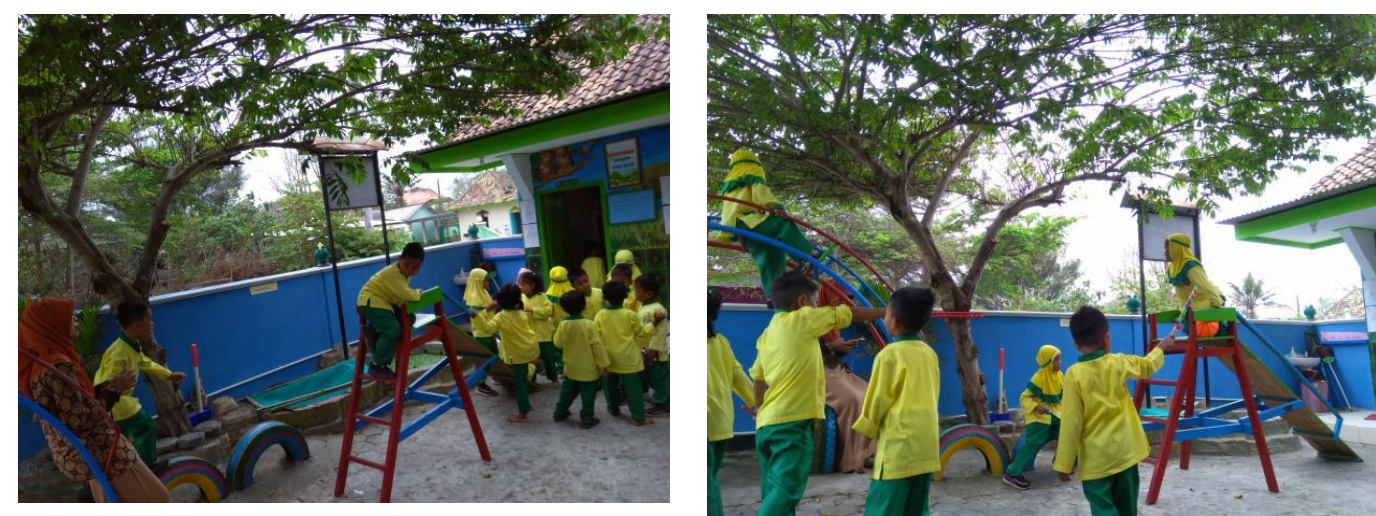

Gambar 2 anak-anak sedang bermain permainan tradisional di halaman sekolah

Saat bermain, ada seorang anak yang menasehati temannya saat melakukan kesalahan. Ada juga anak-anak yang jika kalah bermain akan menangis, sekitar 2-3 anak yang menunjukkan respons seperti itu. Sebagian besar anak-anak bermain sesuai dengan aturan permainan yang berlaku. Anak-anak yang menunjukkan emosi negatif seperti lekas marah dan agresi cenderung dijauhi oleh teman-teman karena mereka dipandang sebagai gangguan. Namun, anak-anak yang ceria dan suka bergaul dicintai oleh anak-anak lain. Ada kelompok "geng" yang terdiri dari 3 wanita dan 1 pria. Kelompok itu selalu duduk dan bermain bersama, jika ada anak-anak lain yang bergabung maka diberi kondisi khusus seperti berbagi makanan, memiliki cerita menarik, dan bisa memiliki minat yang sama.

Pembentukan kelompok "geng" pada usia dini adalah umum karena pada dasarnya anak usia dini suka bermain dalam kelompok jika mereka memiliki minat, usia, dan tingkat kecerdasan yang sama. Guru dan orang tua di pantai selatan Kulon Progo menyadari hal ini sehingga memberi kesempatan kepada anak-anak untuk menemukan teman bermain mereka sendiri. Peran guru dan orang tua mengarahkan anak untuk bersosialisasi dengan orang-orang di sekitarnya. Namun, ada juga orang tua yang masih dominan dalam mengatur hubungan pertemanan anak, misalnya anak mungkin tidak bermain dengan anak yang batuk karena dapat terinfeksi. Bahkan ada orang tua yang ketika mereka melihat anakanak mereka menangis saat bermain kemudian menyalahkan anak-anak lain dan menganggap anak itu sebagai anak yang buruk.

Tindakan orang tua seperti itu mengakibatkan anak-anak menjadi kurang percaya diri dalam bermain, memilih teman, dan menghalangi keterampilan komunikasi. Orang tua harus memberi anak-anak kesempatan untuk bermain dan memilih teman mereka sendiri. Anak usia dini dapat menentukan teman-teman yang sesuai dengan kebutuhan mereka untuk teman-teman dengan arahan yang diberikan dari orang tua, bukan perilaku yang mengatur dengan siapa anak dapat bermain, di mana, dan permainan apa yang mungkin dimainkan.

Permainan tradisional memiliki peran yang sangat penting dalam perkembangan sosial dan emosional, kognitif, fisik dan motorik, dan perkembangan bahasa pada anak usia dini. Sebagian besar permainan tradisional dimainkan dalam kelompok, sehingga dapat 
merangsang kompetensi sosial dan emosional anak-anak. Anak-anak di pesisir selatan Kulon Progo yang sering bermain permainan tradisional menunjukkan keterampilan sosial dan emosional yang lebih baik dibandingkan dengan anak-anak yang tidak. Anak-anak belajar bagaimana menyelesaikan masalah, berkomunikasi, dan mengendalikan emosi (Petrovska et al., 2013).

\section{SIMPULAN}

Berdasarkan uraian di atas, dapat disimpulkan bahwa keterampilan sosial dan emosional anak usia dini di pantai selatan Kulon Progo menunjukkan tingkat pencapaian perkembangan yang cukup baik. Hubungan teman sebaya yang positif akan meningkatkan prestasi perkembangan sosial dan emosional anak-anak. Bermain dengan teman sebaya dapat memberikan kesempatan bagi anak-anak untuk belajar berbagai hal, terutama belajar berinteraksi dengan orang lain dan mengendalikan emosi sehingga mereka dapat diterima oleh hubungan teman sebaya. Melalui permainan tradisional, anak-anak mendapatkan lebih banyak manfaat dari keterampilan sosial dan emosional dengan cara yang mudah dan menyenangkan. Pentingnya arahan dari orang tua dan guru dalam perkembangan sosial anak-anak perlu direalisasikan dan dipelajari secara mendalam. Namun, sikap orang tua yang terlalu mengatur dapat menghambat kompetensi sosial dan emosional anak-anak.

\section{UCAPAN TERIMAKASIH}

Terima kasih khusus kepada kampus tercinta Universitas Negeri Yogyakarta dan Program Pascasarjana yang telah sangat membantu dalam mendukung penyelesaian artikel ini. Tidak lupa saya mengucapkan terima kasih kepada Prof. Dr. Suparno, M.Pd., yang telah membimbing penulis dalam menyelesaikan artikel ini. Akhirnya, penulis ingin mengucapkan terima kasih kepada keluarga karena telah menjadi inspirasi terbesar dalam segala hal.

\section{DAFTAR PUSTAKA}

Blazevic, I. (2016). Family, Peer and School Influence on Children's Social Development. World Journal of Education, 6(2). https:// doi.org/10.5430/wje.v6n2p42

Buhs, E. S., \& Ladd, G. W. (2001). Peer rejection as an antecedent of young children's school adjustment: an examination of mediating processes. Developmental Psychology, 37(4), 550-560. https://doi.org/10.1037/0012-1649.37.4.550

Carter, C., \& Nutbrown, C. (2016). A Pedagogy of Friendship: young children's friendships and how schools can support them. International Journal of Early Years Education, 24(4), 395-413. https://doi.org/10.1080/09669760.2016.1189813

Clements , D., \& Sarama, J. (2009). Learning and Teaching Early Math: The Learning Trajectories Approach. Routledge.

Denham, S. A. (2006). Social-Emotional Competence as Support for School Readiness: What Is It and How Do We Assess It? Early Education and Development, 17((1)), 57-89.

Gainsley, S. (2013). Building Friendships in Preschool. 27(1), 1-8.

Gleave, J., \& Cole-hamilton, I. (2012). A literature review on the effects of a lack of play on children's lives. January, 34. http://www.playengland.org.uk/media/371031/a-worldwithout-play-literature-review-2012.pdf

Hay, D. F. (2005). Early Peer Relations and their Impact on Children's Development. Development, January 2005, 1-6.

Hurlock, E. B. (1997). Perkembangan Anak: Jilid 1. Erlangga.

Im, G. W., Jiar, Y. K., \& Talib, R. B. (2019). Development of preschool social emotional inventory for preschoolers: A preliminary study. International Journal of Evaluation and Research in Education, 8(1), 158-164. https://doi.org/10.11591/ijere.v8i1.17798 
Keane, S. P., \& Calkins, S. D. (2004). Corruption and unethical behavior: report on a set of Danish guidelines. Journal of Business Ethics, 51(1), 31-39. https:/ / doi.org/10.1023/B

Lestari, P. I., \& Prima, E. (2017). The Implementation of Traditional Games to Improve the Social Emotional Early Childhood. Journal of Educational Science and Technology (EST), 3(3), 178. https:// doi.org/10.26858/est.v3i3.4212

McLaughlin, T., Aspden, K., \& Clarke, L. (2017). 2017 How do teachers support children's social-emotional competence $\square$.pdf. Early Childhood Folio, 21(2), 21-27. https:// doi.org/10.18296/ecf.0041

Nur Aisyah, E. (2017). Character Building in Early Childhood Through Traditional Games. 128(Icet), 292-294. https:/ / doi.org/10.2991/icet-17.2017.51

Papadopoulou, M. (2016). The 'space' of friendship: young children's understandings and expressions of friendship in a reception class. Early Child Development and Care, 186(10), 1544-1558. https:// doi.org/10.1080/03004430.2015.1111879

Parhomenko, K. (2014). Diagnostic Methods of Socio - Emotional Competence in Children. Procedia - Social and Behavioral Sciences, 146, 329-333. https:// doi.org/10.1016/j.sbspro.2014.08.142

Petrovska, S., Sivevska, D., \& Cackov, O. (2013). Role of the Game in the Development of Preschool Child. Procedia - Social and Behavioral Sciences, 92(October 2013), 880-884. https:// doi.org/10.1016/j.sbspro.2013.08.770

Policarpo, V. (2015). What is a friend? An exploratory typology of the meanings of friendship. Social Sciences, 4(1), 171-191. https://doi.org/10.3390/socsci4010171

Shala, M. (2013). The Impact of Preschool Social-Emotional Development on Academic Success of Elementary School Students. Psychology, 04(11), 787-791. https:/ / doi.org/10.4236/psych.2013.411112

Sugiyono. (2013). Metode Penelitian Kuantitatif, Kualitatitf, dan RED. Alfabeta.

Sulistyaningtyas, R. E., \& Fauziah, P. Y. (2019). The Implementation of Traditional Games for Early Childhood Education. July. https:// doi.org/10.2991/iccie-18.2019.75

Theobald, M., Danby, S., Thompson, C., \& Thorpe, K. (n.d.). Friendships_in_the_early_years_Theobaldetal_submitted.

Tufekčić, A. (2016). Popularisation of Traditional Children' S Games Through InformationCommunication Technology. 01(01), 33-44. https://doi.org/10.15503/edut.2016.1.33.44

Unesco. (2013). Traditional Games: Honing Skills and Dexterity. Unesco.

Unicef. (2018). Learning through play; Strengthening learning through play in early childhood education programmes. LEGO FOUNDATION.

van Hoogdalem, A. G., Singer, E., Eek, A., \& Heesbeen, D. (2013). Friendship in young children: Construction of a behavioural sociometric method. Journal of Early Childhood Research, 11(3), 236-247. https://doi.org/10.1177/1476718X13488337

Whitebread, D., Neale, D., Jensen, H., Liu, C., S., \& S.L., Hopkins, E., Hirsh-Pasek, K. Zosh, J. M. (2017). The role of play in children's development: a review of the evidence (Issue November).

Yu, S. Y., Ostrosky, M. M., \& Fowler, S. A. (2011). Children's friendship development: A comparative study. Early Childhood Research and Practice, 13(1), 1-16. 